\title{
IDENTIFIKASI ANATOMI AKSARA LAMPUNG
}

\author{
Refita Ika Indrayati ${ }^{1}$, Namuri Migotuwio ${ }^{2}$ \\ ${ }^{1}$ Desain Komunikasi Visual, Institut Teknologi Sumatera \\ ${ }^{2}$ Desain Komunikasi Visual, Institut Teknologi Sumatera \\ E-mail: refita.indrayati@dkv.itera.ac.id ${ }^{1}$,namuri.migotuwio@dkv.itera.ac.id ${ }^{2}$
}

\section{ARTICLE INFO}

Article history:

Received: 13 Juli 2020

Revised: 03 Agustus 2020

Accepted: 03 November 2020

Keywords:

Lampung Script

Indonesian Local Script

Typography

\begin{abstract}
ABSTRAK
Writing system in a form of script is an integral part of communication. Its existence enabling history, idea and knowledge to spread beyond one's land and passed from one generation to the other. As a part of Indonesian culture, Lampung script of Had Lampung must be preserved. But in reality, the usage of this script is fading from society. The difficult writing system and wide-spread usage of Latin alphabet as standard in Indonesian language are some of the factors why Lampung script is not a popular writing system in Lampung. This research is trying to fill the gap between the effort of conservation and the lack of documentation about local script. This study uses Type Design Parameter by Mohanty to identify and categorize Lampung script anatomy. This identification can be guideline recommendation for Lampung script based typography design and other purposes.
\end{abstract}

\section{PENDAHULUAN}

Aksara merupakan hasil dari perkembangan cara manusia berkomunikasi. Keberadaan sebuah aksara memungkinkan sejarah, gagasan dan pengetahuan untuk dituliskan dan disebarkan hingga lintas generasi. Sampai saat ini, aksara masih menjadi kebutuhan manusia untuk berkomunikasi, sehingga dapat dikatakan bahwa aksara merupakan salah satu produk yang menunjukkan tingkat peradaban sebuah masyarakat. Karena itu pula, macam aksara berubah seiring dengan perkembangan jaman.

Saat ini terjadi pergeseran dalam penggunaan aksara lokal dalam kehidupan masyarakat modern. Beberapa faktor yang menyebabkan hal tersebut adalah minimnya informasi tentang aksara lokal, sistem penulisan yang sulit, serta penggunaan alphabet latin sebagai standar penulisan bahasa Indonesia. Salah satu aksara lokal yang mulai terancam keberadaannya adalah aksara Lampung. 
Masuknya aksara Lampung sampai saat ini masih kurang jelas. Peneliti kebahasaan seperti van der Tuuk, Hadikusuma dan lain-lain beranggapan bahwa aksara Lampung adalah perkembangan dari aksara Devanagari dari India yang selanjutnya mengalami perkembangan menjadi huruf Palawa (Pudjiastuti, 1998).

Aksara Lampung sendiri akhirnya terbagi menjadi dua, aksara Lampung kuno dan aksara yang telah disederhanakan. Aksara yang digunakan saat ini adalah aksara Lampung yang telah disederhanakan berdasarkan keputusan musyawarah para pemuka adat Lampung pada 23 Februari 1985 (Hadikusuma, 1994). Berdasarkan peraturan pemerintah daerah Lampung nomor 2 tahun 2008 tentang pemeliharaan kebudayaan Lampung, aksara Lampung menjadi unsur kekayaan yang wajib dilestarikan dan dikembangkan.

Untuk mengembangkan aksara Lampung secara luas, bukan hanya melestarikannya dalam bentuk prasasti museum dan pengajaran muatan lokal sekolah. Dibutuhkan pula media yang proaktif menyebarluaskan kekhasan budaya Lampung tersebut. Namun, saat ini penggunaannya hanya terpusat pada infrastruktur sebagai pendamping aksara Latin dan hiasan dalam beberapa produk kreatif di Bandar Lampung. Meskipun baik, penggunaan tersebut belum berusaha menciptakan produk kebudayaan yang komunikatif dan dapat di terima secara masif pada generasi milenial. Dalam kata lain, keberadaan aksara Lampung hanya sebagai citra kebudayaan semata (Budiman, 2019).

Tipografi merupakan bagian yang tidak terpisahkan dari suatu peradaban. Banyak desain huruf yang tersedia hari ini terinspirasi dari desain huruf primitif, dimana karakter digunakan untuk merepresentasikan objek dan konsep (Sihombing, 2001). Perkembangan teknologi dan penggunaan tipografi dalam desain komunikasi visual membuat tampilan yang dapat merepresentasikan konsep saja belum cukup. Huruf yang saat ini dapat di desain dalam format digital membuka peluang tipografer untuk mendesain typeface secara bebas. Dalam proses mendesain typeface inilah tipografer memerlukan kekompakan anatomi visual dan sistem pengukurannya. Aksara lokal yang berkembang secara vernakular tidak memiliki anatomi visual serta ukuran yang baku, sehingga akan menyulitkan penggubahan aksara lokal ke dalam format digital.

Tidak seperti aksara Jawa, Bali ataupun Sunda yang telah memiliki anatomi visual baku, pelestarian aksara Lampung belum didukung oleh sistem visual yang sama. Hal ini memunculkan tampilan visual huruf yang berbeda-beda. Perbedaan tampilan visual huruf bukan hanya berdampak pada pengajaran penulisan aksara, namun juga dapat menghambat pengembangan produk budaya yang mengadaptasi ataupun terinspirasi dari aksara Lampung. 
Salah satu upaya yang dapat dilakukan untuk membenahi masalah tampilan visual adalah membedah anatomi dari aksara Lampung, sehingga didapatkan tampilan visual yang kohesif. Pengkajian anatomi aksara Lampung ini meupakan langkah awal untuk melestarikan budaya Lampung agar dapat diterapkan di berbagai media, khususnya dalam ranah tipografi yang terinspirasi dari aksara lokal.

\section{METODE PENELITIAN}

Metode yang digunakan dalam pembedahan aksara Lampung ini adalah metode kualitatif deskriptif. Terdapat dua tahap analisis; Pengumpulan data serta proses kategorisasi dan proses identifikasi. Dalam proses kategori dan identifikasi menggunakan parameter dari metode Type Design (Mohanty, 1998). Parameter tersebut diantaranya melihat aksara dari segi character and sctructural parameter (kerupaan huruf mulai dari karakter dan struktur huruf), width parameter (skala panjang dan lebar huruf), proportion parameter (penentuan garis bantu pada huruf yang telah ditambahkan tanda baca), grid parameter (tata tulis horizontal pada sebuah set huruf) dan spacing parameter (jarak antar seluruh elemen huruf). Hasil analisis yang telah dilakukan selanjutnya disimpulkan untuk selanjutnya dapat menjadi rekomendasi pembakuan visual aksara Lampung.

\section{PEMBAHASAN}

\subsection{Deskripsi Data}

Aksara Lampung yang digunakan saat ini terdiri dari huruf induk (kelabai surat), anak huruf (benah surat) dan tanda-tanda baca (Pudjiastuti, 1998). Sedangkan angka dan tanda baca dalam aksara Lampung menggunakan tanda baca latin dan angka arab dan romawi. Huruf induk dalam aksara Lampung berjumlah 20 buah yang ditulis dan dibaca dari kiri ke kanan. Anak huruf dalam aksara Lampung berfungsi sebagai penambah vocal dalam huruf induk. Terdapat 12 buah anak huruf yang dapat diletakan di atas, di bawah, maupun di kanan huruf induk.

Mengingat penggunaan aksara Lampung baru (yang telah mengalami penyederhanaan) di masyarakat Lampung, penelitian ini mengambil dua bentuk huruf induk aksara Lampung dari buku pembelajaran aksara Lampung untuk pendidikan muatan lokal. Buku tersebut adalah Aksara dan Naskah Kuno Lampung dalam Pandangan Masyarakat Lampung Kini karya Tuti Pudjiastuti dan Ngulam I : Pelajaran Bahasa Lampung Dialek Abung Tulang Bawang karya Hilman Hadikusuma. Acuan data mengenai bentuk dua huruf induk tersebut adalah sebagai berikut: 

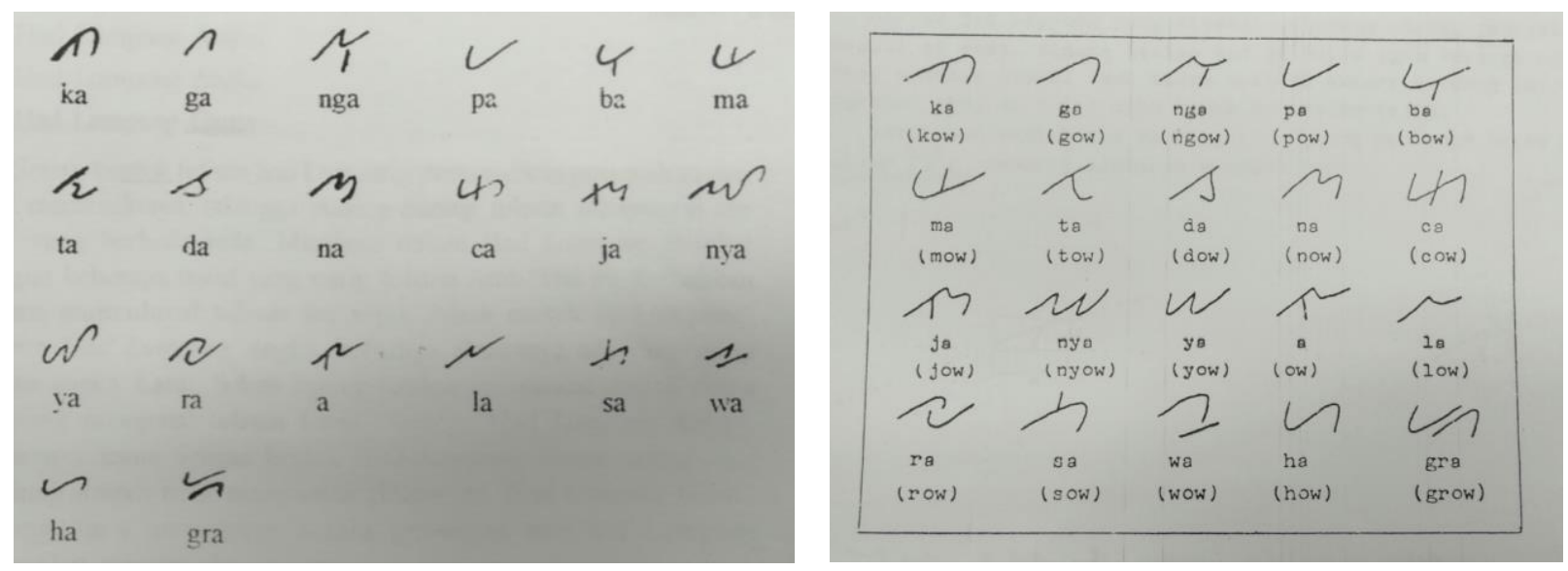

Gambar 1. Contoh dua set bentuk aksara Lampung yang digunakan sebagai acuan data.

(Sumber: Dokumentasi Penulis)

\subsection{Pembahasan}

\section{1) Character and Stuctural Parameter}

Garis merupakan bagian dasar dalam pembentukan struktur dan karakter tipografi. Jika dibedah, setiap bentuk aksara terdiri dari kombinasi garis tegak datar, tegak miring, tegak lengkung, dan lengkung (Haswanto, 2002). Dalam aksara Lampung, garis tersebut dapat dibagi menjadi lima kelompok; garis lengkung (cekung dan cembung), garis campuran lengkung atas-tegak, garis campuran lengkung bawah-tegak, garis lengkung rangkap, dan garis lengkung rangkap dengan garis tegak. Kelompok garis tersebut dapat dilihat pada gambar berikut:

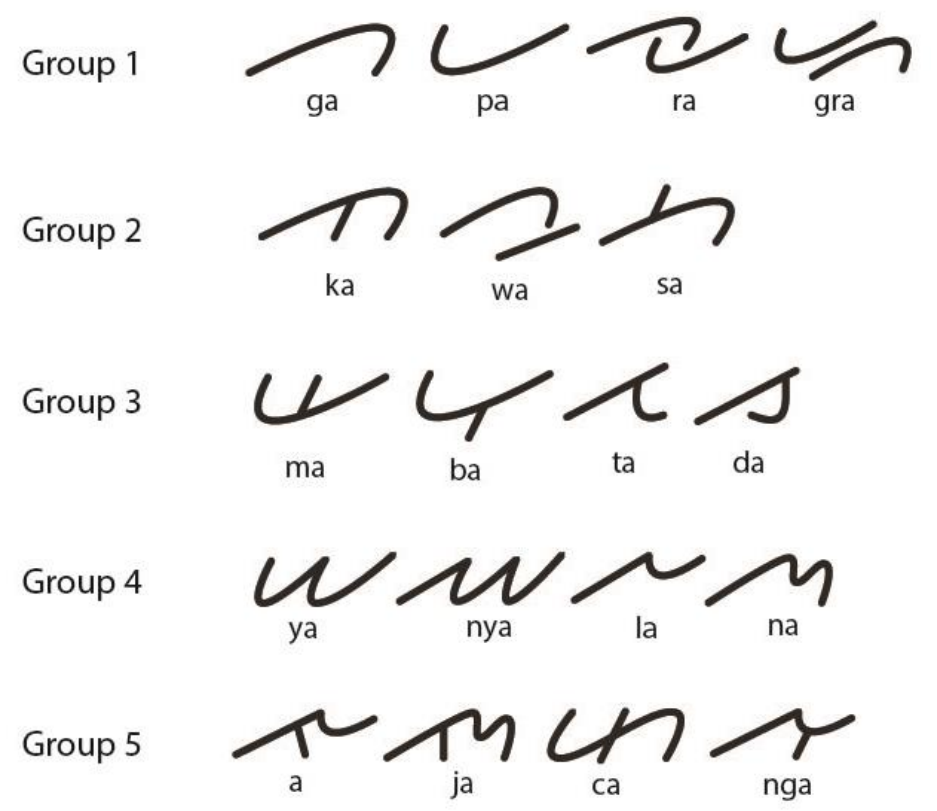

Gambar 2. Lima kelompok garis pembentuk dasar huruf dalam aksara Lampung 
(Sumber: Dokumentasi Penulis)

Karakter aksara Lampung tidak hanya dapat dilihat dari bentuk garis saja, namun bagian pembentuk anatomi aksara Lampung. Setidaknya terdapat 12 bagian yang dapat diidentifikasi dalam huruf induk aksara Lampung. Bagian anatomi tersebut dapat dijelaskan dalam tabel sebagai berikut:

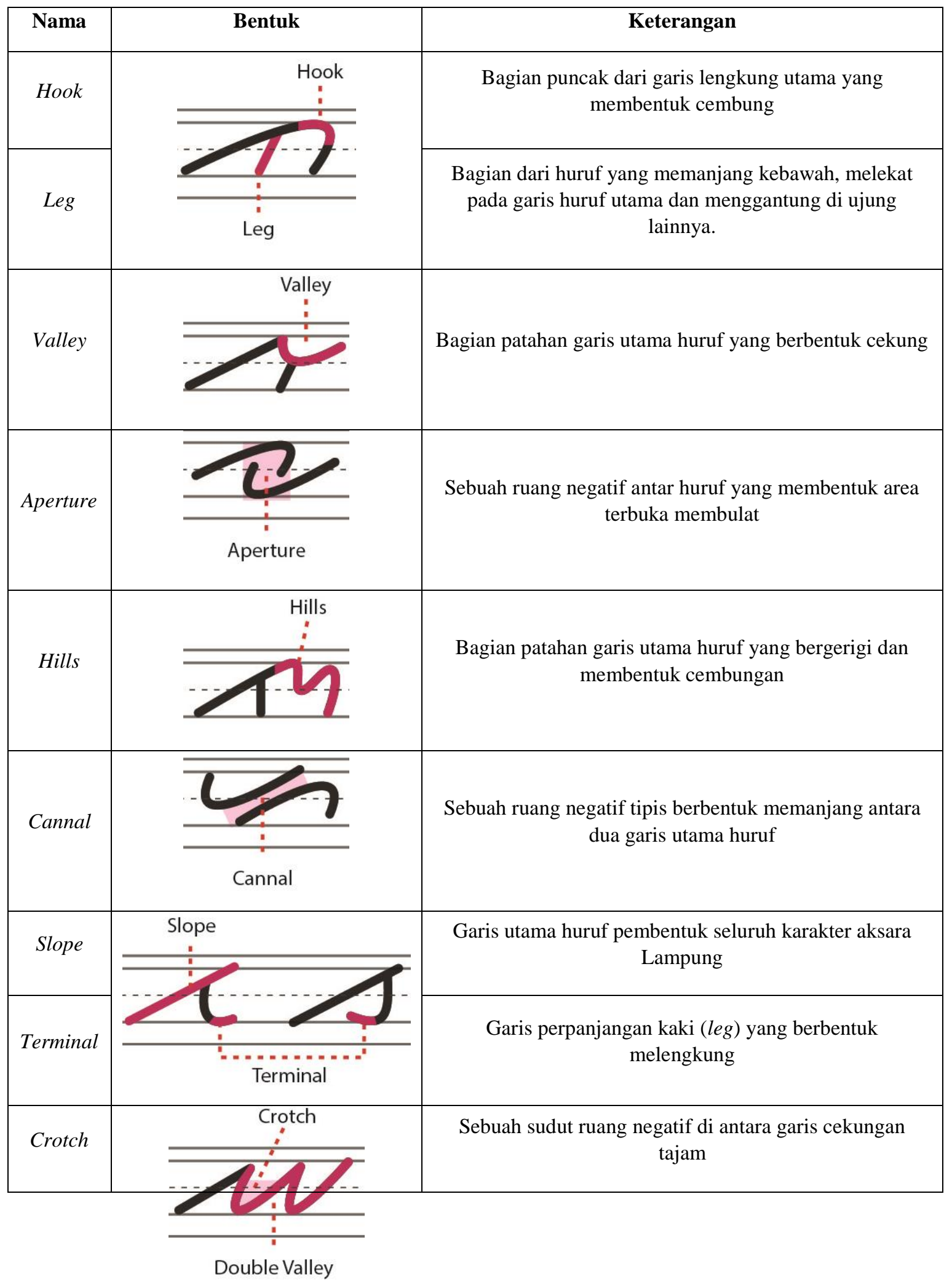




\begin{tabular}{|c|c|c|}
\hline $\begin{array}{c}\text { Double } \\
\text { Valley }\end{array}$ & & Garis cekung dengan sudut tajam yang berulang \\
\hline $\begin{array}{c}\text { Diagonal } \\
\text { Stroke }\end{array}$ & Diagonal & Garis diagonal yang memotong garis utama \\
\hline Arm & Arm & \\
\hline
\end{tabular}

Tabel 1: Anatomi Huruf Induk Aksara Lampung

(Sumber: Dokumentasi Penulis)

\section{2) Character and Stuctural Parameter}

Ukuran huruf menentukan panduan untuk merancang jarak yang harmonis antar huruf dalam sebuah teks. Aksara Lampung sendiri memiliki bentuk persegi panjang dengan orientasi memanjang ke samping. Rasio ukuran huruf induk dalam aksara Lampung bervariasi, namun memiliki tinggi yang sama.

Karena variasi tersebut, aksara Lampung memiliki bentuk unik yang dapat digolongkan menjadi tujuh kategori rasio yang dijabarkan dalam ilustrasi berikut:

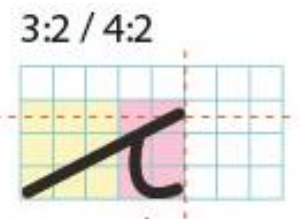

ta

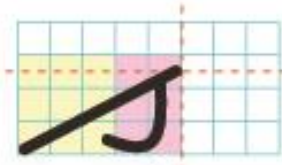

da

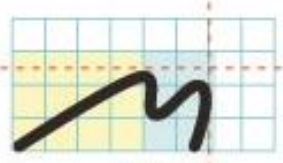

na

$6: 1$

$3: 2: 2$

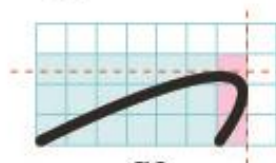

ga

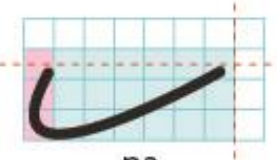

pa

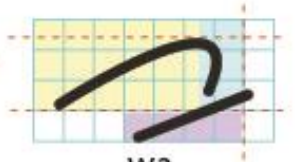

wa

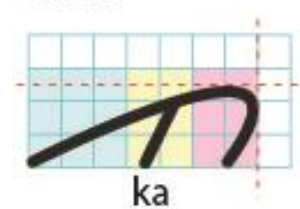

ka

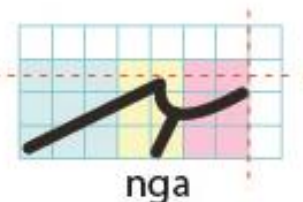

nga

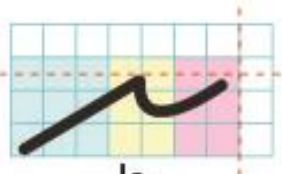

la

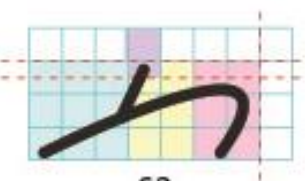

sa

Gambar 3. Kategori besar huruf induk aksara Lampung dengan rasio 3:2/4:2, 6:1, dan 3:2:2

(Sumber: Dokumentasi Penulis) 


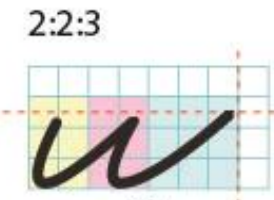

ya

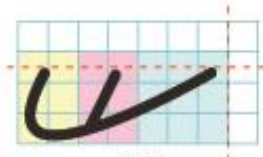

ma

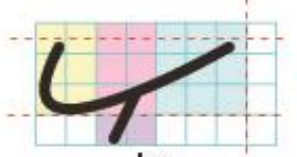

ba

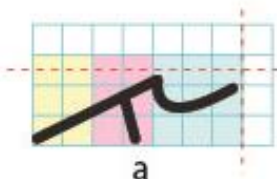

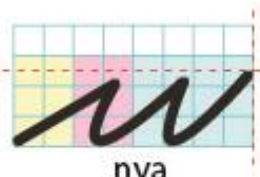

nya

2:3:2

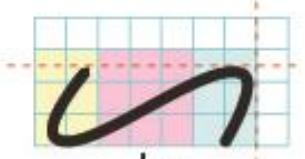

ha

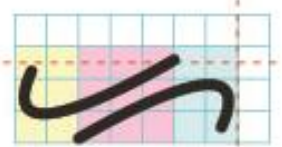

gra

\section{$2: 2: 2$}

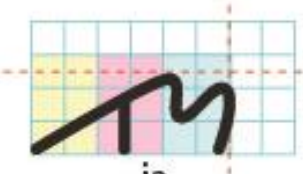

ja

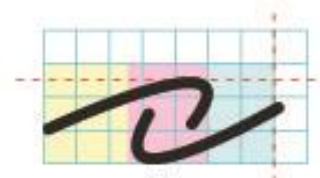

ra

\section{$3: 1: 3$}

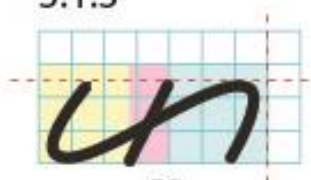

Ca

Gambar 4. Kategori besar huruf induk aksara Lampung dengan rasio 2:2:3, 2:3:2, 2:2:2, dan 3:1:3 (Sumber: Dokumentasi Penulis)

Berdasarkan gambar di atas, rasio huruf induk aksara Lampung cenderung berada di antara panjang 5 hingga 7 kotak dengan tinggi 3 kotak. Tinggi tersebut konstan pada seluruh huruf induk, kecuali huruf 'wa', 'ba' dan 'sa' yang masing-masing memiliki tinggi 4 kotak untuk mewadahi kelebihan garis yang dikategorikan sebagai ascender dan descender. Rasio tersebut membuat aksara Lampung secara visual terlihat pipih dan memanjang.

\section{3) Proportion Parameter}

Proporsi huruf menentukan kedudukan huruf dalam garis horizontal. Garis proporsi meliputi baseline (garis horizontal dimana huruf berdiri), capline (garis horizontal yang menandakan bagian tertinggi sebuah huruf), dan meanline (garis imajiner yang menandakan tinggi huruf induk). Diakritik atau tanda bunyi juga penting dalam sistem pembacaan aksara Lampung. Terdapat tiga sistem penempatan diakritik dalam aksara Lampung yaitu; di atas 
huruf induk (top diacritics), di bawah huruf induk (middle diacritics), dan di bawah huruf induk (bottom diacritics).

Proporsi penempatan huruf induk dan diakritik yang tepat menentukan kesatuan dan kemudahan pembacaan aksara Lampung. Identifikasi kedua penempatan tersebut adalah sebagai berikut:

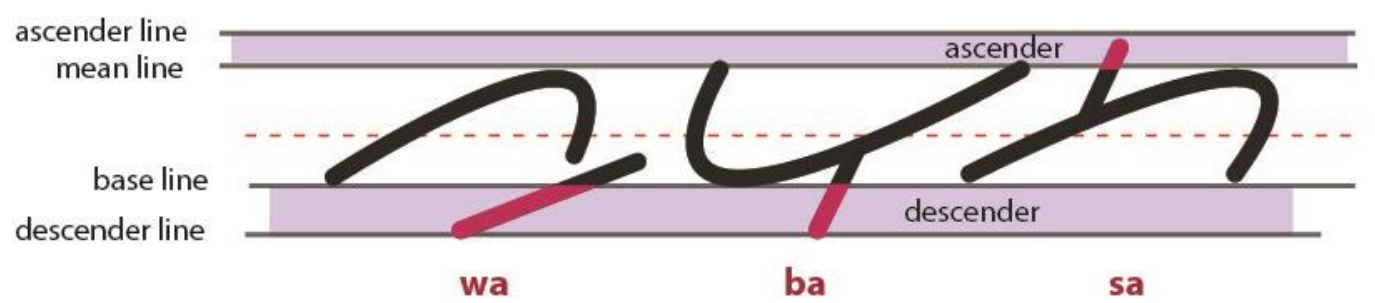

Gambar 5. Contoh identifikasi garis proporsi huruf induk aksara Lampung (Sumber: Dokumentasi Penulis)

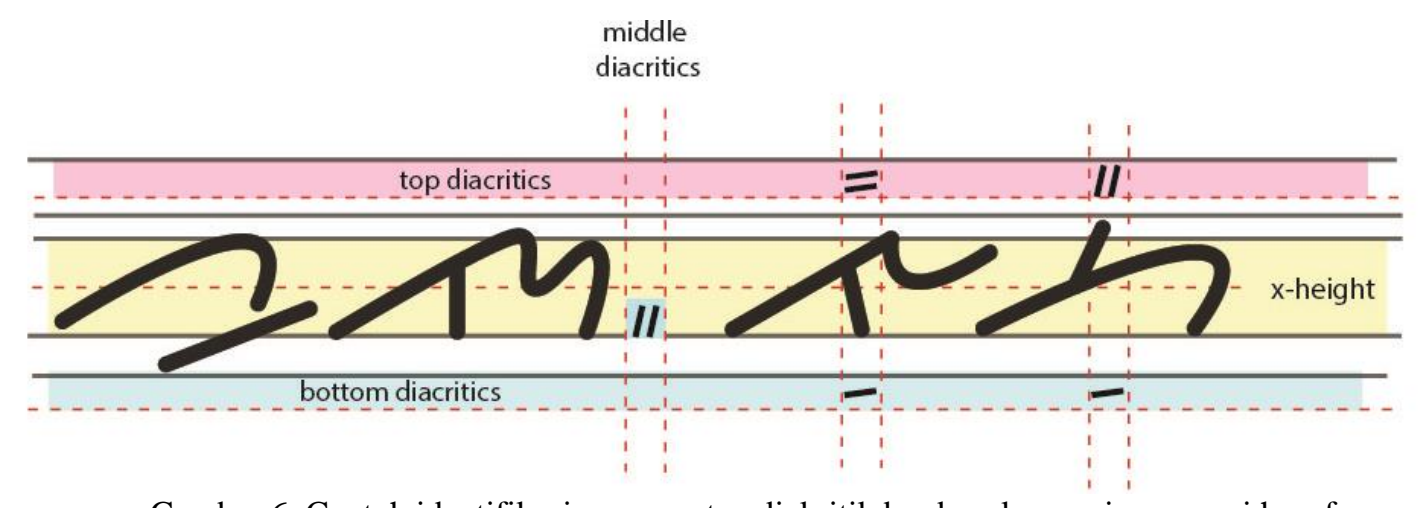

Gambar 6. Contoh identifikasi penempatan diakritik berdasarkan garis proporsi huruf (Sumber: Dokumentasi Penulis)

Rata-rata posisi aksara Lampung memenuhi bagian $x$-height dengan pengecualian huruf induk 'wa' dan 'ba' yang memiliki descender, serta huruf induk 'sa' yang memiliki ascender seperti yang ditampilkan pada gambar di atas. Ukuran descender dan ascender tersebut memengaruhi penempatan diakritik. Dalam gambar 5, terlihat bagian descender pada huruf induk aksara Lapung lebih besar dari ascender. Hal tersebut berpengaruh pada penempatan diakritik pada gambar 6, dimana diakritik yang diletakan di bawah huruf induk memerlukan ruang spasi lebih besar daripada diakritik yang diletakan di atas huruf induk.

\section{4) Spacing Parameter}

Komposisi bidang negatif dan positif serta ukuran huruf yang seimbang akan menentukan keterbacaan sebuah desain tipografi. Spasi antar huruf atau kerning adalah penyesuaian yang harus dilakukan dengan mempertimbangkan ukuran serta struktur garis dari huruf yang saling bertemu. Penyesuaian ini dilakukan secara manual dan unik pada masing-masing 
huruf. Berdasarkan karakter aksara Lampung yang telah dijabarkan pada poin anatomi, terdapat dua kombinasi komposisi huruf induk yang dominan dan berpengaruh pada pengaturan jarak antar huruf induk. Kombinasi pertama adalah pertemuan slope dengan karakter garis cembung / cekung (dan sebaliknya), serta kombinasi kedua yaitu pertemuan antara dua slope.

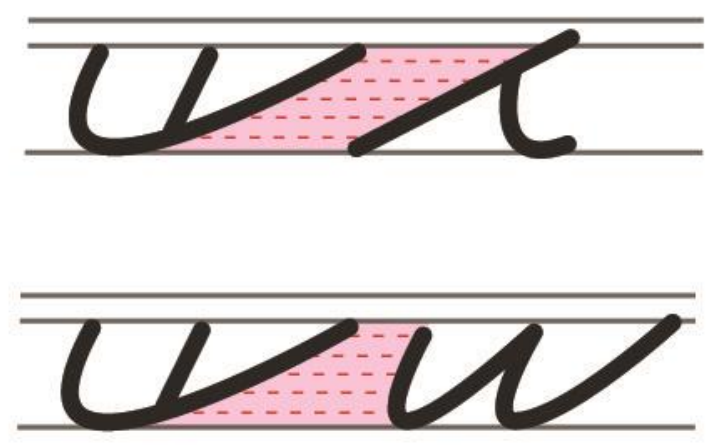

Gambar 7. Contoh perbedaan jarak kerning pada dua pasang kombinasi huruf induk aksara Lampung (Sumber: Dokumentasi Penulis)

Perbedaan kerning pada kombinasi di atas menunjukkan kebutuhan ruang spasi yang berbeda antar karakter huruf satu dengan lainnya. Pada komposisi b (bagian bawah), karakter garis slope yang bertemu dengan garis cekung membutuhkan jarak spasi yang lebih besar untuk menghindari overlap pada titik pertemuan garis akhir slope dan awal garis double valley. Sementara komposisi a (bagian atas) dapat disusun secara lebih rapat karena dua huruf induk memiliki garis yang sejajar.

\section{5) Grid Parameter}

Komposisi penempatan seluruh komponen dalam mendesain huruf ditentukan dengan sistem grid. Ketika parameter spasi membahas tentang keseimbangan antara dua huruf induk, parameter grid lebih membahas tentang pengukuran penempatan diakritik dalam huruf induk. Meskipun poin proporsi dan spasi sedikit banyak sudah menyinggung perkiraan skala ukuran, penyesuaian grid perlu dilakukan melihat dua cara penggunan diakritik (tunggal dan ganda) dalam aksara Lampung. Berikut adalah perkiraan skala huruf induk beserta diakritik dalam grid: 


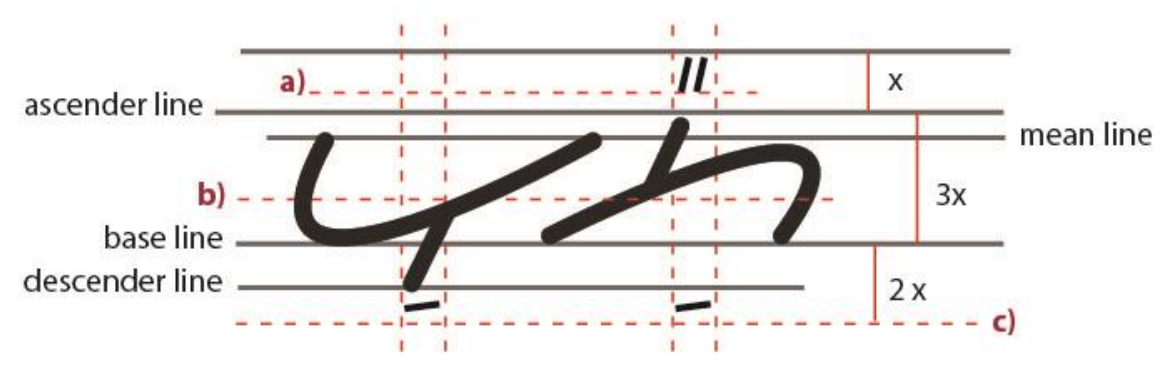

a. base line for top diacritics

b. top line for middle diacritics

c. base line for bottom diacritics

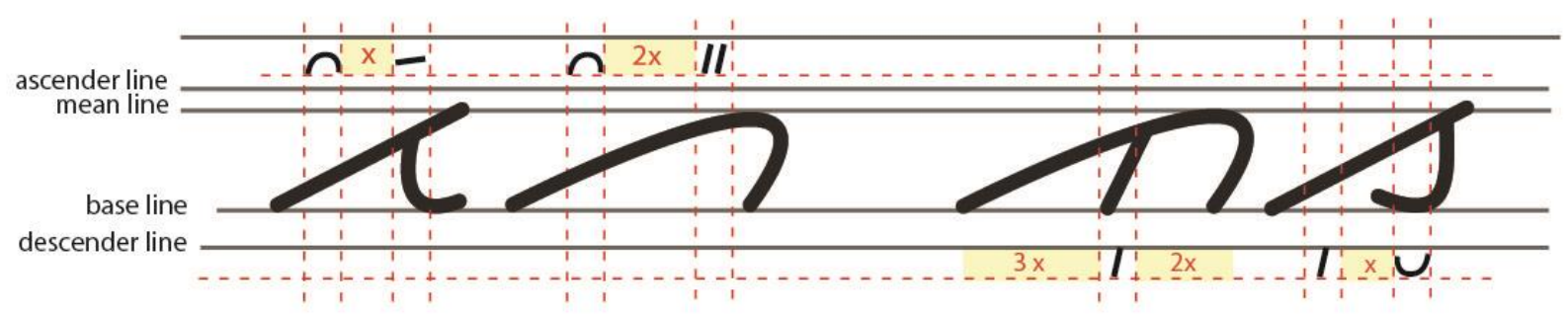

Gambar 8. Contoh perkiraan skala ukuran huruf induk dan penempatan diakritik aksara Lampung (Sumber: Dokumentasi Penulis)

Secara keseluruhan, skala penempatan huruf induk dan diakritik (top diacritics dan bottom diacritics) aksara Lampung adalah 1:3:2 (gambar 8 atas). Sementara, skala penggunaan diakritik tunggal dan ganda diperjelas dalam gambar 8 bawah. Diakritik yang diletakan pada huruf induk dengan rasio 3:2 / 4:2 (ujung kanan dan ujung kiri) memerlukan spasi yang lebih kecil daripada diakritik yang diletakan pada huruf induk dengan rasio 3:2:2 (ketiga dari kiri) atau 6:1 (kedua dari kiri). Perlu diperhatikan bahwa jarak antar diakritik ini menyesuaikan dengan jarak ruang negatif yang dihasilkan masing-masing huruf induk.

\section{KESIMPULAN}

Pengukuran struktur dan anatomi merupakan rangka awal dalam mendesain sebuah huruf. Tanpa kedua hal tesebut, desain yang dihasilkan menjadi tidak jelas dan akan berujung pada tingkat keterbacaan aksara. Aksara Lampung pada dasarnya memiliki keunikan yang berbeda dari aksara nusantara lainnya. Keunikan tersebut dapat dilihat dari bentuk dan karakter aksara Lampung sendiri.

Parameter karakter dan struktur, ukuran huruf, proporsi huruf, spasi antar huruf, dan grid adalah beberapa hal yang harus dipertimbangkan ketika mentransformasi aksara Lampung ke dalam tampilan yang lebih modern. Rekomendasi yang ditawarkan dalam penelitian ini diharapkan mampu memberi garis besar pengembangan tampilan visual aksara Lampung untuk tipografer, desainer ataupun computer scientist. Pengaplikasian parameter ini akhirnya tidak 
hanya mengulik ranah proporsi objek bentuk secara presisi, namun juga potensi untuk mengembangkan estetika bentuk huruf dan kaitannya dengan keterbacaan.

\section{DAFTAR PUSTAKA}

Pudjiastuti, T., 1996. Aksara dan Naskah Kuno Lampung dalam Pandangan Masyarakat Lampung Kini. Jakarta: Departemen Pendidikan dan Kebudayaan RI.

Hadikusuma, H., 1994. Ngulam I : Pembelajaran Bahasa Lampung Dialek Abung Tulang Bawang. Bandar Lampung: Departemen Pendidikan dan Kebudayaan Provinsi Lampung.

Budiman, A. dkk., 2019. Revisualisasi Aksara Kaganga sebagai Identitas Lampung. Jurnal Bahasa Rupa, Vol. 2, No. 2. Hal: 118-125.

Sihombing, D., 2001. Tipografi dalam Desain Grafis. Jakarta: Gramedia Pustaka Utama.

Mohanty, S.K., 1998. The Formulation of Parameters for Type Design of Indian Scripts Based on Calligraphic Studies. Electronic Publishing, Artistic Imaging, and Digital Typography. Lecture Notes in Computer Science, Vol. 1375. Hal:157-166.

Haswanto, N., 2002. Tinjauan Rupa atas Aksara Batak Toba sebagai Sumber Gagasan Bagi Tipografi Masa Kini. Tesis. Bandung: Institut Teknologi Bandung. 